.

\title{
Melanocortin receptor accessory proteins in adrenal gland physiology and beyond
}

\author{
T V Novoselova, D Jackson, D C Campbell, A J L Clark and L F Chan
}

Centre for Endocrinology, Queen Mary University of London, William Harvey Research Institute, Barts and the London School of Medicine and Dentistry, Charterhouse Square, London EC1M6BQ, UK.

Correspondence

should be addressed to

LF Chan

Email

I.chan@qmul.ac.uk

\begin{abstract}
The melanocortin receptor (MCR) family consists of five G-protein-coupled receptors (MC1R-MC5R) with diverse physiological roles. MC1R controls pigmentation, MC2R is a critical component of the hypothalamic-pituitary-adrenal axis, MC3R and MC4R have a vital role in energy homeostasis and MC5R is involved in exocrine function. The melanocortin receptor accessory protein (MRAP) and its paralogue MRAP2 are small single-pass transmembrane proteins that have been shown to regulate MCR expression and function. In the adrenal gland, MRAP is an essential accessory factor for the functional expression of the $\mathrm{MC2R} / \mathrm{ACTH}$ receptor. The importance of MRAP in adrenal gland physiology is demonstrated by the clinical condition familial glucocorticoid deficiency, where inactivating MRAP mutations account for $\sim 20 \%$ of cases. MRAP is highly expressed in both the zona fasciculata and the undifferentiated zone. Expression in the undifferentiated zone suggests that MRAP could also be important in adrenal cell differentiation and/or maintenance. In contrast, the role of adrenal MRAP2, which is highly expressed in the foetal gland, is unclear. The expression of MRAPs outside the adrenal gland is suggestive of a wider physiological purpose, beyond MC2R-mediated adrenal steroidogenesis. In vitro, MRAPs have been shown to reduce surface expression and signalling of all the other MCRs (MC1,3,4,5R). MRAP2 is predominantly expressed in the hypothalamus, a site that also expresses a high level of MC3R and MC4R. This raises the intriguing possibility of a CNS role for the MRAPs.
\end{abstract}
Key Words
- MRAPs
- Melanocortin receptor
- HPA axis
- Adrenal cortex

Journal of Endocrinology (2013) 217, R1-R11

\section{Hypothalamic-pituitary-adrenal axis}

The adrenal glands are responsible for releasing different classes of hormones. The inner part of the glands, the medulla, secretes catecholamines under the control of the sympathetic nervous system. The outer part, the cortex, has three functionally distinct layers - the outer zona glomerulosa that secretes aldosterone, the middle zona fasciculata that produces glucocorticoids and the inner zona reticularis that is responsible for the production of adrenal androgens. Production and release of glucocorticoids by the zona fasciculata are tightly regulated by the hypothalamus and pituitary to control diurnal cortisol levels and the rapid increase of cortisol secretion during emotional or physical stress. Stress triggers a number of brain circuits such as brainstem catecholamine-producing pathways that cause excitation of the parvocellular neurons of the hypothalamic paraventricular nucleus (PVN; reviewed in Herman \& Cullinan (1997) and Arnsten (2009)). In response to stress, these neurons start secreting corticotropin-releasing hormone

Published by Bioscientifica Ltd 
(CRH) and arginine vasopressin (AVP) (Sawchenko \& Swanson 1985) into the hypophyseal portal circulation. Both CRH and AVP trigger secretion of ACTH by cells of the anterior pituitary gland (Vale et al. 1981, Aguilera et al. 1983). ACTH is produced by cleavage from its precursor proopiomelanocortin (POMC), as are $\alpha$-, $\beta$ - and $\gamma$-melanocyte-stimulating hormones (MSHs). ACTH is released into the circulation to act on peripheral sites, mainly the adrenal glands, to stimulate glucocorticoid hormone production. Glucocorticoids negatively feedback to regulate the release of CRH and AVP at the hypothalamus and ACTH at the pituitary, thus providing tight regulation of cortisol production (Fig. 1). This regulatory system is termed the hypothalamic-pituitaryadrenal (HPA) axis, and perturbations of this system have been shown to be involved in a wide range of physiological processes and diseases such as Cushing's syndrome, adrenal insufficiency, depression and sepsis.

\section{Melanocortin 2 receptor is a critical component of the HPA axis}

Melanocortin receptors (MCRs) are a subfamily of seven-transmembrane (TM)-domain G-protein-coupled receptors (GPCRs) that mediate signalling of hormones derived from POMC such as ACTH and MSHs (Mountjoy et al. 1992, Cone et al. 1993). To date, five MCRs have been described, and they have been shown to have a diverse range of functions. MC1R controls skin pigmentation (Valverde et al. 1995), MC3R and MC4R are major contributors to the regulation of food intake and energy homeostasis (Marsh et al. 1999, Butler et al. 2000, Chen et al. 2000) and MC5R is highly expressed during embryogenesis but in adults is believed to be involved in exocrine function (Labbe et al. 1994, Chagnon et al. 1997, Ogawa et al. 2004). MC1,3,4,5R respond to all POMCderived hormones (ACTH and $\alpha$-, $\beta$ - and $\gamma$-MSH) but differ in ligand preference, whereas MC2R responds to ACTH only (Cone et al. 1993). Binding of ACTH to MC2R results in increase of cAMP and activation of protein kinase A, which is essential for the expression of steroidogenic enzymes and cortisol production. MC2R appears to be positively regulated by its ligand (Hofland et al. 2012), and some studies have suggested a rare involvement of MC2R in adrenal cortisol-secreting tumours (Latronico et al. 1995, Arnaldi et al. 1998). MC2R is predominantly expressed in all zones of the adrenal cortex, but ACTH mostly acts on the zona fasciculata (Mountjoy et al. 1992). ACTH activation in zona reticularis stimulates the production of adrenal androgens (Weber et al. 1997).

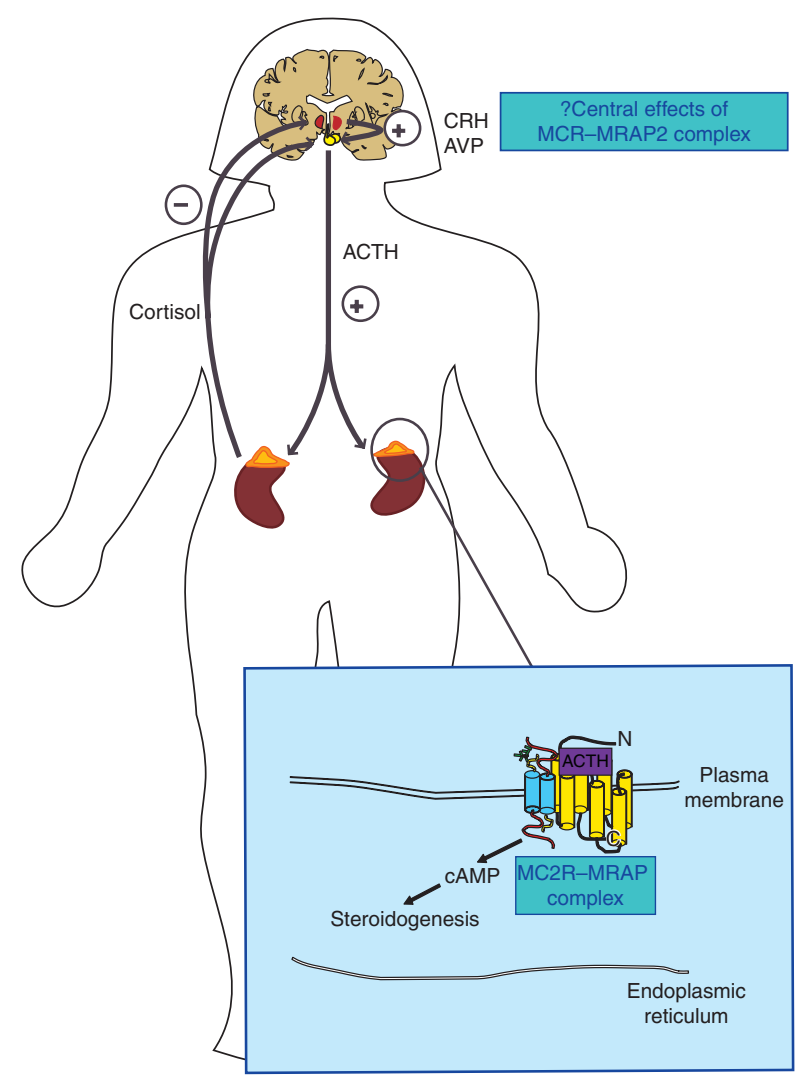

Figure 1

Schematic overview of the HPA axis and the sites of predominant MRAP/MRAP2 action. In short, CRH and AVP at the hypothalamus stimulate ACTH production in the anterior pituitary gland. ACTH released into the circulation acts on the adrenal cortex to produce glucocorticoids (cortisol in humans and corticosterone in rodents). Glucocorticoids negatively feedback to regulate the release of CRH and AVP at the hypothalamus and ACTH at the pituitary. MC2R and MRAP act predominantly in the adrenal cortex as demonstrated by patients with isolated cortisol deficiency caused by deleterious mutations in MC2R and MRAP. The function of MRAP2 is yet unclear, although it is thought to have a predominant central effect due to its expression in the hypothalamus.

Failure of MC2R to activate in response to ACTH causes familial glucocorticoid deficiency (FGD; Clark et al. 1993), a rare autosomal recessive disorder characterised by severe cortisol deficiency with high plasma ACTH levels and normal mineralocorticoid levels (Shepard et al. 1959, Clark \& Weber 1998). Untreated, FGD is lethal in early childhood, usually due to profound hypoglycaemia or overwhelming infection. MC2R mutations resulting in effective loss of the receptor function are responsible for FGD type 1, which accounts for up to $25 \%$ of all FGD cases (Clark et al. 2005). MC2R activating mutations are extremely rare, and to date only one (F278C) has been reported, which was found in a patient with cyclical Cushing's syndrome (Swords et al. 2002). The same

Published by Bioscientifica Ltd. 
mutation was found in conjunction with a non-activating mutation presenting with FGD (Chan et al. 2009a). The majority of MC2R mutations result in defective trafficking of the receptor to the plasma membrane (Chung et al. 2008).

Functional expression of MC2R in cell lines of nonadrenal origin (heterologous cells) is notoriously difficult and results in retention of $\mathrm{MC} 2 \mathrm{R}$ in the endoplasmic reticulum (ER) and unresponsiveness of such cells to ACTH (Schimmer et al. 1995). It was suggested that a specific factor, present in the adrenal gland, is essential for human MC2R function (Noon et al. 2002). This phenomenon is observed with all described MC2Rs in vertebrates apart from cartilaginous fish (elephant shark) where the $\mathrm{MC} 2 \mathrm{R}$ can reach the plasma membrane and function in non-adrenal cells and responds not only to ACTH but to MSHs as well. It is suggested that the unique properties of MC2R such as selectivity to ACTH and requirement of the adrenal specific factor emerged after the divergence of the ancestral cartilaginous and bony fishes more than 400 million years ago (Reinick et al. 2012).

\section{Melanocortin 2 receptor accessory protein and adrenal gland physiology}

A genetic screening of patients with FGD but with normal MC2R identified a number of nonsense and splice site mutations in the C21ORF61 gene that would result in a complete absence or a short truncated protein thought to undergo rapid degradation if translated at all (Metherell et al. 2005). The gene product had previously been named fat tissue-specific low molecular weight protein due to its expression in differentiating adipocyte cells, but its function had been unknown (Xu et al. 2002). Further expression analysis revealed that this protein was highly expressed in the adrenal gland with lower expression levels in other tissues such as brain, thyroid, ovary, testis and breast (Metherell et al. 2005). From finding that mutations of this gene underlie $\sim 20 \%$ cases of FGD, now known as FGD type 2, and that the protein was predominantly expressed in the adrenal gland, it was hypothesised that it could be the adrenal specific factor required for MC2R functional expression. It was shown that this protein was able to interact with MC2R and thus, the new protein was named melanocortin receptor 2 accessory protein (MRAP; Metherell et al. 2005). MRAP was shown to localise to the ER and plasma membrane, and its co-expression with MC2R in heterologous cells resulted in a significant proportion of the receptor being delivered to the plasma membrane. Moreover, such cells became ACTH responsive, thus showing that MRAP was the adrenal specific factor required for MC2R function (Metherell et al. 2005). Later studies confirmed that MRAP is essential for trafficking of MC2R to the plasma membrane and its function. In the mouse adrenocortical Y1 cell line that endogenously expresses both MC2R and MRAP and responds to ACTH stimulation, knockdown of MRAP by shRNA resulted in loss of response to ACTH, which was rescued by overexpression of the shRNA-insensitive human MRAP (Cooray et al. 2008). Both MRAP and MC2R are highly expressed in the zona fasciculata in glucocorticoid-producing cells, with the highest expression levels in undifferentiated zone (Gorrigan et al. 2011), which is directly adjacent to zona fasciculata and is believed to contain stem cells that contribute to steroidogenic cell maintenance (Mitani et al. 2003). These data suggest that MC2R and MRAP are important for adrenal gland development, and the adrenal histology of FGD supports this hypothesis as the glands from deceased patients demonstrate disorganisation of glomerulosa cells with almost complete absence of fasciculata and reticularis cells (Clark \& Weber 1998). It has also been demonstrated that in vivo, mRNA levels of both MC2R and MRAP in the adrenal gland are regulated by ACTH (Xing et al. 2010, Hofland et al. 2012). However, at times of acute stress, the immediate steroidogenic response would depend on adequate levels of MRAP and MC2R at the surface and that can be readily trafficked to the plasma membrane. MRAP and MC2R that can be readily trafficked to the plasma membrane. Furthermore, pulsatility of MRAP transcription induced by pulsatile administration of ACTH in rats leads to the suggestion that adrenocortical responsiveness and expression of steroidogenic enzymes are ultimately determined by the availability of MC2R at the cell surface (Spiga et al. 2011).

The MRAP protein comprises 172 amino acids and consists of a highly evolutionarily conserved $\mathrm{N}$-terminus and a single TM domain followed by a less conserved C-terminus (reviewed in Webb \& Clark (2010)). MRAP has a unique previously uncharacterised topology (Sebag \& Hinkle 2007). It forms a stable antiparallel homodimer at the plasma membrane and in the ER. The seven amino acids flanking the TM domain from the N-terminus are essential for this dual topology (Sebag \& Hinkle 2007, 2009a,b, Cooray et al. 2008; Fig. 2). Importantly, MRAP forms a stable heterodimer with MC2R and this heterodimer is present at the plasma membrane (Sebag \& Hinkle 2009b). Co-immunoprecipitation studies using MRAP fragments mapped the interaction domain to between amino acids 36 and 62; this region includes the entire TM

Published by Bioscientifica Ltd. 
(a)

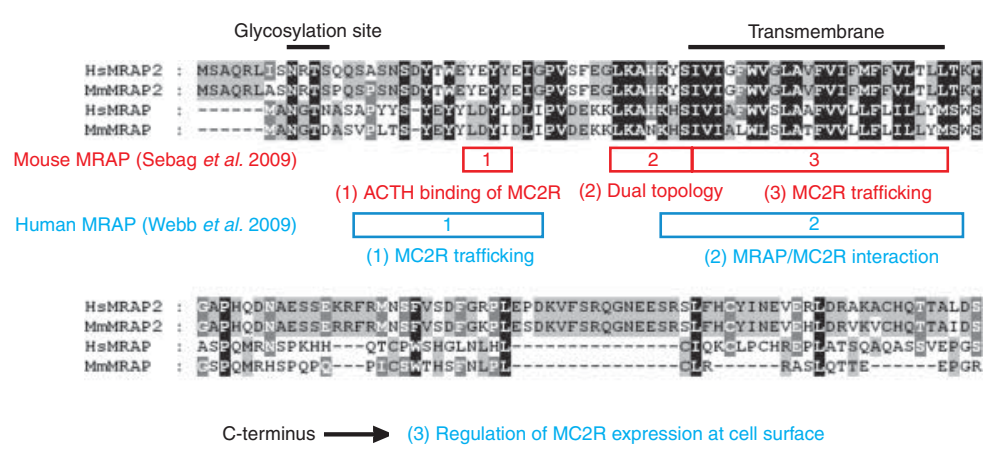

HSMRAP2 : DVQLOEATRSSGQPEEEZWRLMKFD I PNFVWTD QWYFGEDDULISEPP IVLETKPLSQT SHKDLD MIMRAP2 : DVHLCBAS SSGRPEEELARFMKFDIPNFVHTEQSSFGEDDLLISEAPVLLEMKPVSQTSRIDLD HSMRAP : RTGPDQPLRQESSSTLPLGGFQTHPTLLWELW---LHGGPLURIKPSEPPPGDRTGOLQS-.--

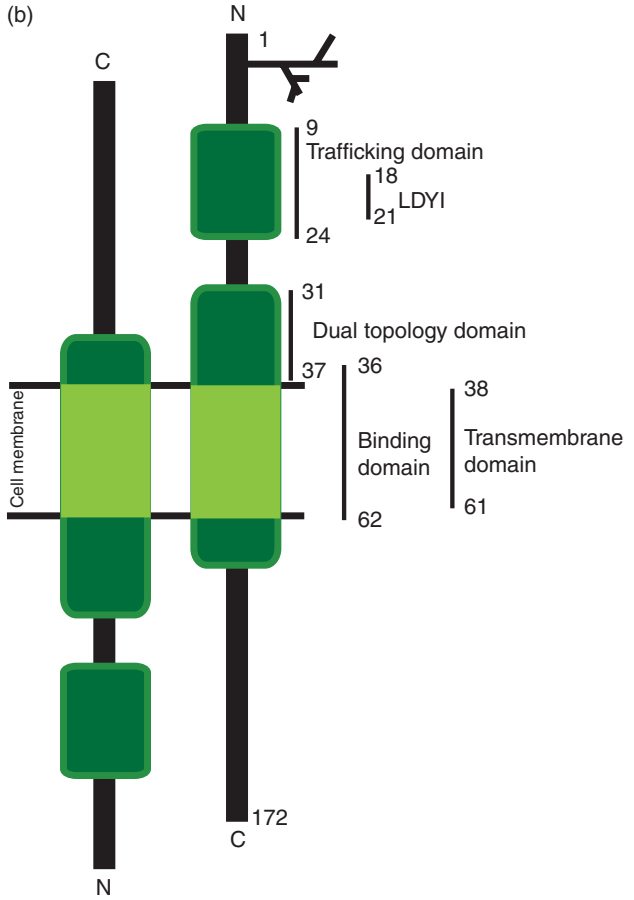

\section{Figure 2}

Regions of MRAP action. (A) Protein alignment of mouse and human MRAP proteins with schematic representation of identified functional domains. Work on human MRAP by Webb et al. identified two functional domains involved in MC2R trafficking and MRAP/MC2R interaction. There was also a possible suggestion that the $C$-terminus could regulate $M C 2 R$ surface expression (Webb et al. 2009). In comparison, work on mouse MRAP has

domain and several flanking amino acids (Webb et al. 2009). It is suggested that the dual topology of MRAP is important for trafficking of $\mathrm{MC} 2 \mathrm{R}$ as deletion of the residues responsible for antiparallel dimerisation resulted in failure to traffic the receptor to the plasma membrane (Sebag \& Hinkle 2009b). However, the deletion of the dimerisation region also removes a residue in the MC2R binding domain, which may affect MRAP/receptor binding and hence trafficking. Interestingly, a tyrosine-rich region in the N-terminus (amino acids 9-24) is required for MC2R trafficking to the plasma membrane and this region is similar to those in other GPCR accessory proteins, such as odorant receptor accessory protein REEP1 (Saito et al. 2004, Webb et al. 2009). Moreover, upon deletion within this region, at residues 18-21 (LDYI), MRAP was able to traffic MC2R to the plasma membrane surface but MC2R failed to respond to $\mathrm{ACTH}$, indicating that probably these four amino acids facilitate receptor-ligand binding (Sebag \& Hinkle 2009b).

Two MRAP isoforms with differing C-termini have been described in humans - MRAP $\alpha(19 \mathrm{kDa})$ and MRAP $\beta$ revealed three possible essential domains involved with ACTH binding of MC2R, dual topology and MC2R trafficking (Sebag \& Hinkle 2009a,b). Hs, Homo sapiens; Mm, Mus musculus. (B) Schematic representation of human MRAP adopting an antiparallel form. Dark green boxes denote amino acid regions of interest whilst the light green area demonstrates the transmembrane domain.

(14 kDa), a shorter isoform produced by alternative splicing. The precise function of the variable C-terminal domain of MRAP remains to be fully elucidated. The isoforms are expressed in the adrenal gland at similar levels, but the precise role of each isoform remains unclear (Metherell et al. 2005, Webb et al. 2009). Deletion of the whole C-terminus causes a decrease in the ACTH response of MC2R-expressing cells (Roy et al. 2012). Some studies have demonstrated that expression of the shorter isoform, MRAP $\beta$, leads to higher MC2R surface expression, suggesting it may regulate MC2R internalisation rate (Roy et al. 2007, Webb et al. 2009). Recently, another study (Roy et al. 2012) demonstrated that MRAP $\alpha$ localised mainly in the ER, whereas MRAP $\beta$ exhibited a strong localisation at the plasma membrane. Although both MRAP isoforms and the C-terminally truncated construct were able to facilitate surface expression of MC2R, it was co-expression of MRAP $\beta$ and MC2R that resulted in the highest cAMP production upon stimulation with ACTH (Roy et al. 2012). These data suggest that the C-terminus may determine intracellular

Published by Bioscientifica Ltd. 
localisation of MRAP and potentially increase MC2R affinity to its ligand or facilitate MC2R signalling, but this hypothesis needs further validation.

\section{MRAP2 in the adrenal gland}

Recently, a homologue of MRAP highly conserved through vertebrates was identified having 39\% amino acid sequence identity within the $\mathrm{N}$-terminus, again with a single-pass TM domain, and it was named MRAP2 (Chan et al. 2009b). The degree of conservation of MRAP2 across species is much higher compared with MRAP, suggesting that MRAP2 is the ancestral gene (Webb \& Clark 2010). It has been shown that in rodents, MRAP2 is expressed in developing adrenals, but the expression levels are very low in adulthood (Gorrigan et al. 2011). Expression has also been demonstrated in brain, mainly in the hypothalamus (Lein et al. 2007, Chan et al. 2009b, Gorrigan et al. 2011). In contrast, a more ubiquitous pattern of expression has been shown in zebrafish MRAP2 (Agulleiro et al. 2010). MRAP2 is slightly bigger than MRAP, comprising 205 amino acids $(23.5 \mathrm{kDa})$, and has a glycosylation site NRTS at positions 9-12. It is likely to form antiparallel homodimers, and intracellular localisation of MRAP2 also matches the intracellular distribution of its homologue MRAP (Chan et al. 2009b). Cell expression studies showed that MRAP2 was able to form a complex with MC2R, facilitate its trafficking, and enable receptor signalling in response to ACTH. MRAP2 is also able to form stable heterodimers with MRAP when co-expressed in cell lines (Chan et al. 2009b). However, the role of MRAP/MRAP2 heterodimers remains to be elucidated as one study demonstrated negative regulation of the MRAP/MC2R complex by MRAP2 (Sebag \& Hinkle 2010), whereas other studies demonstrated either no effect on the signalling properties of the MC2R/MRAP complex (Gorrigan et al. 2011) or that MRAP2 augments MC2R signalling (Agulleiro et al. 2010). A study of human adrenocortical tissues demonstrated an association between patient ACTH and cortisol levels and adrenal expression of MRAP and MC2R, but not MRAP2 (Hofland et al. 2012). Mutation of the glycosylation site of MRAP2 abolishes $\mathrm{MC} 2 \mathrm{R}$ response to ACTH but does not affect facilitation of MC2R surface expression, suggesting that MRAP2 might have two separate accessory roles (Chan et al. 2009b). Interestingly, MC2R-MRAP2 complex requires 1000 times higher ACTH concentration than the ACTH amount needed for the MC2R-MRAP complex to trigger the same cAMP production (Gorrigan et al. 2011). This difference can be reversed by inserting residues LDYI, not conserved between MRAP and MRAP2, into the MRAP2 protein sequence (Sebag \& Hinkle 2009b). Based on all the data described above, it would be tempting to hypothesise that both MRAPs regulate the dose response of MC2R to ACTH. However, patients with FGD type 2 have plasma ACTH levels elevated hundreds of times above normal, and according to this hypothesis, such levels would enable signalling via the MC2R-MRAP2 complex in the absence of MRAP, whereas in fact intact MRAP2 is unable to compensate for the loss of MRAP, suggesting that interaction with $\mathrm{MC} 2 \mathrm{R}$ is not the main function of MRAP2 in vivo. However, an MRAP2 adrenal role cannot be excluded, as MRAP2 is expressed in the developing adrenal gland, which suggests its involvement in the adrenal development (Gorrigan et al. 2011). Thus, the function of MRAP2 interaction with MC2R and its relationships with MRAP require further investigation using in vivo models.

\section{MRAP and MRAP2 function beyond the adrenal gland}

The relatively wide expression patterns of both MRAP and MRAP2 suggest that they may have other functions. Although MC2R expression is mostly restricted to the adrenal glands, low levels are also detected in the skin and lymphocytes (Mountjoy et al. 1992, Slominski et al. 1996, Andersen et al. 2005), and the role of MC2R and MRAPs in these tissues is unknown. The importance of MC2R expression in lymphocytes such as natural killer and $\mathrm{T}$ helper $\left(\mathrm{CD}^{+}\right)$cells (Andersen et al. 2005) is difficult to assess as lack of glucocorticoids in FGD patients compromises the immune system via a number of mechanisms (Clark et al. 1993, Lowenberg et al. 2008).

MC2R is also expressed in adipose tissue together with MC5R where they mediate the potent lipolytic effects of ACTH and $\alpha$-MSH (reviewed in Boston (1999) and Wikberg (1999)). At the same time, there is evidence that signalling mediated by MC2R and MC5R in adipocytes inhibits production of leptin, a hormone that completes a nutritional feedback loop to the hypothalamus (Zhang et al. 1994, Maffei et al. 1995), indicating that possibly there is a control mechanism for modulation of adipose tissue function via a melanocortin-leptin axis (Norman et al. 2003). MRAP was initially identified as a small protein upregulated in the differentiating mouse adipocyte 3T3-L1 cell line (Xu et al. 2002) and more recently was shown to be highly upregulated in the differentiation of mesenchymal stem cells into adipocytes, pointing to a role in adipogenesis (Menssen et al. 2011).

Published by Bioscientifica Ltd. 
Interestingly, MC2R has a wide expression pattern during embryonic development and is also present in placenta in rodents (Izumi et al. 2004, Nimura et al. 2006). Placenta produces ACTH along with other pituitary-like peptides, and human foetal plasma ACTH levels are higher than those in maternal plasma (Krieger 1982, Petraglia et al. 1987), indicating the importance of ACTH during embryogenesis. In rodents, MC2R is highly expressed in a developing adrenal gland and is also found in lung where its function may be important for glucocorticoidmediated lung maturation (Simard et al. 2010). MC2R is detected in developing testes where it may have a role in testosterone production by Leydig cells at an early stage of embryogenesis (O'Shaughnessy et al. 2003). MC2R is also found at different stages in the foetal brain, choroid plexus, genital ridge, mesonephros, metanephros and dorsal root and trigeminal ganglia, but its role in these tissues has not been investigated (Nimura et al. 2006). However, FGD type 1 patients with MC2R mutations are not known to have any congenital abnormalities other than glucocorticoid deficiency. Detailed study of MRAP and MRAP2 expression patterns during development would probably shed light on MC2R function regulation in the foetus.

Importantly, MRAP and MRAP2 are able to interact with all other MCRs, which broadens the potential range of MRAP function (Chan et al. 2009b; Fig. 3). For instance, in vitro, both MRAPs interact with MC4R but act in the opposite way to their effect on MC2R. Co-expression of MRAP and/or MRAP2 with MC4R in heterologous cells results in decreased surface expression of the receptor and reduction of signalling in response to NDP-MSH (Chan et al. 2009b). MC4R is highly expressed in PVN of the hypothalamus and nucleus accumbens and is involved in food intake regulation. Mutations in the $M C 4 R$ gene are associated with severe obesity in early childhood (Vaisse et al. 1998, Yeo et al. 1998, Lee et al. 2008), and studies using knockout Mc4r mice showed that this obesity is due to hyperphagia (Huszar et al. 1997, Marsh et al. 1999). The majority of these mutations lead to intracellular retention of the receptor and lack of MC4R signalling (Farooqi et al. 2003, Lubrano-Berthelier et al. 2003) and have been reported in $\sim 2-6 \%$ of the population. Polymorphisms V103I and I251L are thought to increase MC4R signalling, and affected individuals exhibit low body mass index (Stutzmann et al. 2007). MC4R signalling mediates some pathways of the stress response, and MC4R activation has been shown to result in anhedonia with weight loss (Lim et al. 2012). Hence, future drug targeting of MRAPs/MC4R could potentially alter appetite intake and body weight.
Both MRAPs interact with MC3R, which is involved in body weight and energy metabolism regulation. MRAPs regulate MC3R signalling but not surface expression, supporting the hypothesis of a dual functional role for MRAP proteins (Chan et al. 2009b). MC3R is highly expressed in ventromedial and arcuate nuclei of the hypothalamus. In knockout mice lacking the $M c 3 r$ gene, nutrients are preferentially partitioned into fat at the expense of lean mass, resulting in a reduction in locomotor activity and fine movements (Chen et al. 2000). Importantly, increased feed efficiency, not hyperphagia, causes weight increase in these mice (Chen et al. 2000). In humans, several polymorphisms of the MC3R gene are associated with high insulin levels and obesity in children (Feng et al. 2005). Although both MRAPs reduce MC3R signalling, it is more likely that MRAP2 regulates MC3R in vivo as both are mostly expressed in the hypothalamus. With the exception of one family, altered body weight has not been observed in patients with MRAP mutations, suggesting that MRAP may not be the key hypothalamic player (Rumie et al. 2007). However, this does not exclude the possibility of MC3R regulation by MRAP in other tissues where MC3R is also expressed such as in adipose tissue, heart (Chagnon et al. 1997), skeletal muscle, kidney (Chhajlani 1996), stomach, duodenum, placenta, pancreas (Gantz et al. 1993) and immunocompetent cells (Getting et al. 1999, Lindberg et al. 2005).

Another interesting interaction is with MC5R where both MRAPs have a significant negative effect on this receptor's surface expression and signalling. Despite a very wide expression pattern, the function of MC5R is mostly associated with exocrine regulation, and Mc5r knockout mice exhibit severe defects in water repulsion and thermoregulation due to decreased production of sebaceous lipids (Chen et al. 1997). Interestingly, MC5R mediates a pheromonal signal for aggression in mice (Morgan \& Cone 2006). Previous work has indicated the requirement of $\alpha$-MSH in aldosterone production from the zona glomerulosa (Vinson et al. 1980, Shenker et al. 1985, Costa et al. 2011). As MC5R is expressed in the zona fasciculata, it has been suggested that $\alpha$-MSH may act through the MC5R, although this has yet to be verified. Along with MC2R, MC5R is also believed to play an important part in embryogenesis, having a similar tissue distribution. However, MC5R unlike MC2R is not found in placenta, is expressed at different stages, and therefore probably has a different role from MC2R (Nimura et al. 2006, Simamura et al. 2010). Mouse embryonic stem cells express MC5R instead of other MCRs and MC5R is suggested to be involved in the regulation of stem cell propagation

Published by Bioscientifica Ltd 
A

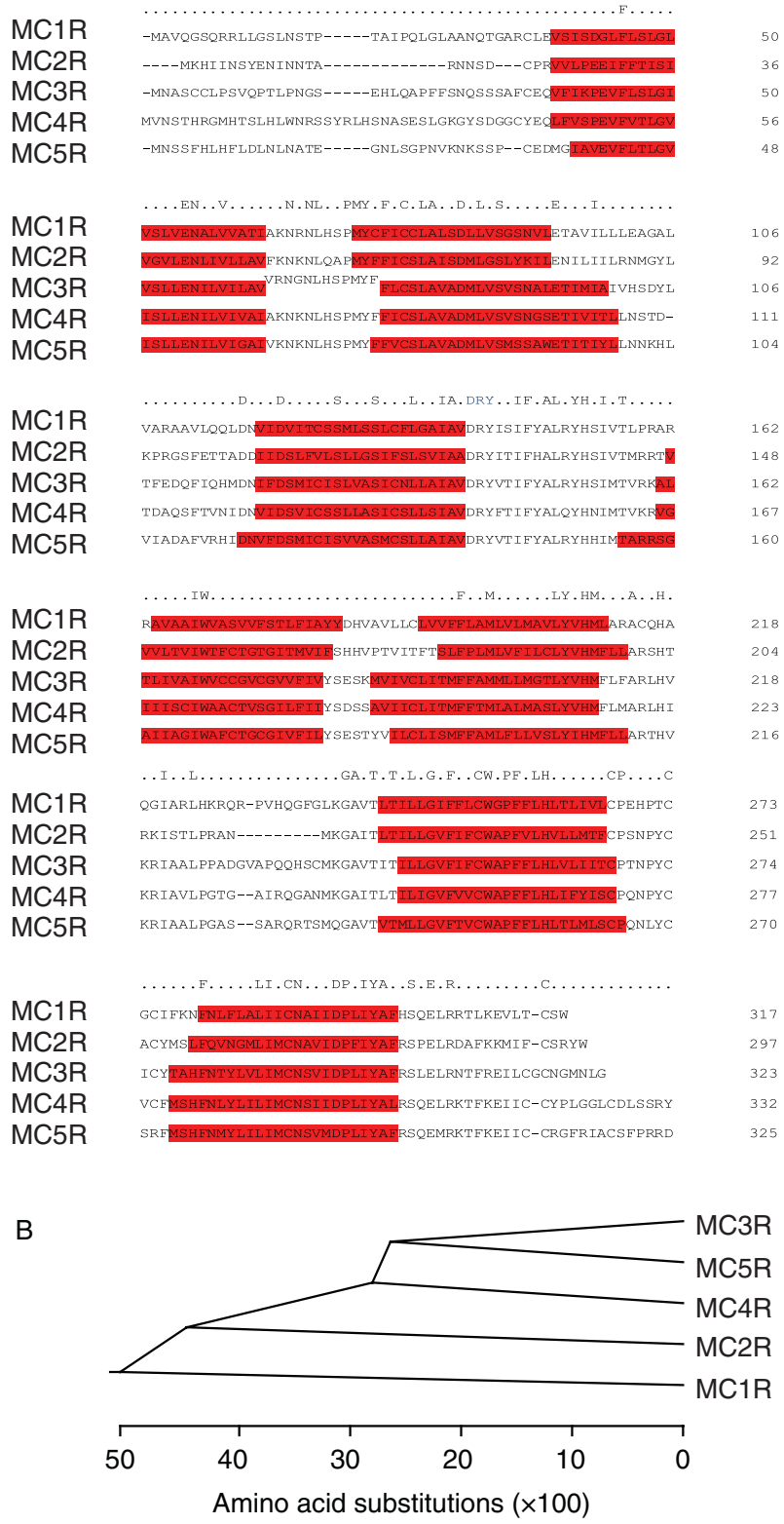

Figure 3

Conservation of the melanocortin receptors. (A) Alignment (ClustalW) of the protein sequences of human melanocortin receptors (NCBI, MC1R NP_002377.4, MC2R NP_000520.1, MC3R NP_063941.3, MC4R NP_005903.2 and MC5R NP_005904.1). The classical feature of the GPCR family, seven predicted TM regions, is highlighted in red. The amino acids identical between all five receptors are shown above the alignment. Because MRAPs interact with all the melanocortin receptors, it is tempting to suggest that via a single TM domain, MRAPs bind MCRs within the regions of highest similarity between the receptors such as TM2, TM5 and TM6. (B) Phylogenetic tree of the melanocortin receptors showing evolutionary relationships within this GPCR family.
(Ogawa et al. 2004). In cultured B-lymphocytes, $\alpha$-MSH binding to MC5R activates the Jak/Stat pathway that is normally activated by cytokines, indicating that MC5R might have some function during immune response (Buggy 1998). It would be interesting to investigate whether regulation of MC5R by MRAPs has any role in the above functions of MC5R, perhaps revealing another level of GPCR regulation in vivo.

There is little suggestion of a role for MRAP in MC1R regulation as there is no significant effect on its surface expression and signalling. MRAP2 has a slight inhibitory effect on MC1R signalling without affecting the receptor presence on the plasma membrane (Chan et al. 2009b). There is no evidence for MRAP2 being expressed in the skin where MC1R is believed to function (Robbins et al. 1993). Using immunohistochemistry, it was shown that MC1R might be expressed in the placenta (Thornwall et al. 1997), but whether MRAP2 is expressed in this tissue or whether it has a regulatory role there is not known.

Interestingly, patients with FGD exhibit a dark skin colour, which is thought to be due to elevated ACTH levels acting on MC1R receptors expressed in melanocytes (Chung et al. 2010). This suggestion is supported by the recent case of a patient with FGD with mutations in both MC2R and MC1R who exhibited normal skin colour (Turan et al. 2012). It has also been proposed that changes in MC1R function can be associated with poor tanning response and melanoma (Valverde et al. 1995, 1996). There is some evidence that skin has an equivalent of the HPA regulated by MC1R and MC2R and is able to secrete cortisol (Ito et al. 2005), and MRAPs may potentially have a regulatory function on MCRs here.

Another potential role of MRAPs in signalling mediated by MCRs could be in manipulating their ligand preference. It is known that only MC2R responds to ACTH alone, whereas all the other MCRs also bind other POMCderived peptides but with different affinities (Cone et al. 1993). The effect of MRAPs on the other MCRs' signalling has mostly been studied using a synthetic $\alpha$-MSH (Chan et al. 2009b, Sebag \& Hinkle 2009b, 2010). However, it is known that MC3R is activated by $\gamma$-MSH and ACTH rather than $\alpha$-MSH, and MRAPs possibly have a different effect on MC3R signalling in response to these two hormones rather than the suppression shown for $\alpha$-MSH (Roselli-Rehfuss et al. 1993, Chan et al. 2009b). MC4R responds to $\alpha$-MSH with the same affinity as for ACTH, but the binding to these different ligands may result in distinct pathways being triggered within the cell. How accessory proteins regulate the affinity of these receptors for different POMC peptides needs further elucidation. The interaction of

Published by Bioscientifica Ltd 
MRAP2 with MC3R and MC4R is particularly intriguing as they all have hypothalamic expression; future studies will uncover physiological functions of MRAP2. The interplay between MRAP and MRAP2 in MCR regulation during embryonic development and into adulthood requires further investigation.

\section{Conclusions}

The melanocortin family of proteins has diverse roles in the regulation of physiological processes. Identifying mutations in MC2R as causative of FGD triggered years of intensive research on MC2R regulation. Finding its accessory protein MRAP, where mutations result in FGD type 2, provided further insight into the regulation of MC2R function. MRAP regulates MC2R surface expression and facilitates its signalling. The role of the MRAP homologue, MRAP2, in relation to MC2R regulation needs exploration. However, it is more likely that the function of MRAP2 lies beyond MC2R and adrenal physiology. It is likely that MRAP2 is involved in the functioning of other MCRs such as MC4R and/or MC3R, thereby in the central regulation of energy metabolism and food intake. MRAP and MRAP2 may also have a role as regulators of MCRs during embryonic development. Further studies using animal transgenic models and genetic analysis are needed to elucidate in vivo functions of MRAP and MRAP2 and their importance. Understanding these functions will allow future research to develop new therapies for diseases caused by MCR dysfunction.

\section{Declaration of interest}

The authors declare that there is no conflict of interest that could be perceived as prejudicing the impartiality of the review reported.

\section{Funding}

Research on MRAPs is supported by an MRC/Academy of Medical Sciences Clinician Scientist Fellowship to L F C (grant number G0802796).

\section{Acknowledgements}

This article is based on the presentation by $\mathrm{Dr} L \mathrm{~J}$ Chan for the JOE/JME Prize Lecture 2012 at ICE/ECE 2012, Florence, Italy.

\section{References}

Aguilera G, Harwood JP, Wilson JX, Morell J, Brown JH \& Catt KJ 1983 Mechanisms of action of corticotropin-releasing factor and other regulators of corticotropin release in rat pituitary cells. Journal of Biological Chemistry 258 8039-8045.
Agulleiro MJ, Roy S, Sanchez E, Puchol S, Gallo-Payet N \& Cerda-Reverter JM 2010 Role of melanocortin receptor accessory proteins in the function of zebrafish melanocortin receptor type 2. Molecular and Cellular Endocrinology 320 145-152. (doi:10.1016/j.mce.2010.01.032)

Andersen GN, Hagglund M, Nagaeva O, Frangsmyr L, Petrovska R, Mincheva-Nilsson L \& Wikberg JE 2005 Quantitative measurement of the levels of melanocortin receptor subtype 1, 2, 3 and 5 and pro-opiomelanocortin peptide gene expression in subsets of human peripheral blood leucocytes. Scandinavian Journal of Immunology 61 279-284. (doi:10.1111/j.1365-3083.2005.01565.x)

Arnaldi G, Mancini V, Costantini C, Giovagnetti M, Petrelli M, Masini A, Bertagna X \& Mantero F 1998 ACTH receptor mRNA in human adrenocortical tumors: overexpression in aldosteronomas. Endocrine Research 24 845-849. (doi:10.3109/07435809809032695)

Arnsten AF 2009 Stress signalling pathways that impair prefrontal cortex structure and function. Nature Reviews. Neuroscience $10410-422$. (doi:10.1038/nrn2648)

Boston BA 1999 The role of melanocortins in adipocyte function. Annals of the New York Academy of Sciences 885 75-84. (doi:10.1111/j.1749-6632. 1999.tb08666.x)

Buggy JJ 1998 Binding of $\alpha$-melanocyte-stimulating hormone to its G-protein-coupled receptor on B-lymphocytes activates the Jak/STAT pathway. Biochemical Journal 331(Pt 1) 211-216.

Butler AA, Kesterson RA, Khong K, Cullen MJ, Pelleymounter MA, Dekoning J, Baetscher M \& Cone RD 2000 A unique metabolic syndrome causes obesity in the melanocortin-3 receptor-deficient mouse. Endocrinology 141 3518-3521. (doi:10.1210/en.141.9.3518)

Chagnon YC, Chen WJ, Perusse L, Chagnon M, Nadeau A, Wilkison WO \& Bouchard C 1997 Linkage and association studies between the melanocortin receptors 4 and 5 genes and obesity-related phenotypes in the Quebec Family Study. Molecular Medicine 3 663-673.

Chan LF, Chung TT, Massoud AF, Metherell LA \& Clark AJ 2009a Functional consequence of a novel Y129C mutation in a patient with two contradictory melanocortin-2-receptor mutations. European Journal of Endocrinology 160 705-710. (doi:10.1530/EJE-08-0636)

Chan LF, Webb TR, Chung TT, Meimaridou E, Cooray SN, Guasti L, Chapple JP, Egertova M, Elphick MR, Cheetham ME et al. 2009b MRAP and MRAP2 are bidirectional regulators of the melanocortin receptor family. PNAS 106 6146-6151. (doi:10.1073/pnas.0809918106)

Chen W, Kelly MA, Opitz-Araya X, Thomas RE, Low MJ \& Cone RD 1997 Exocrine gland dysfunction in MC5-R-deficient mice: evidence for coordinated regulation of exocrine gland function by melanocortin peptides. Cell 91 789-798. (doi:10.1016/S0092-8674(00)80467-5)

Chen AS, Marsh DJ, Trumbauer ME, Frazier EG, Guan XM, Yu H, Rosenblum CI, Vongs A, Feng Y, Cao L et al. 2000 Inactivation of the mouse melanocortin-3 receptor results in increased fat mass and reduced lean body mass. Nature Genetics 26 97-102. (doi:10.1038/ 79254)

Chhajlani V 1996 Distribution of cDNA for melanocortin receptor subtypes in human tissues. Biochemistry and Molecular Biology International $\mathbf{3 8} 73-80$.

Chung TT, Webb TR, Chan LF, Cooray SN, Metherell LA, King PJ, Chapple JP \& Clark AJ 2008 The majority of adrenocorticotropin receptor (melanocortin 2 receptor) mutations found in familial glucocorticoid deficiency type 1 lead to defective trafficking of the receptor to the cell surface. Journal of Clinical Endocrinology and Metabolism 93 4948-4954. (doi:10.1210/jc.2008-1744)

Chung TT, Chan LF, Metherell LA \& Clark AJ 2010 Phenotypic characteristics of familial glucocorticoid deficiency (FGD) type 1 and 2. Clinical Endocrinology 72 589-594. (doi:10.1111/j.1365-2265.2009. 03663.x)

Clark AJ \& Weber A 1998 Adrenocorticotropin insensitivity syndromes. Endocrine Reviews 19 828-843. (doi:10.1210/er.19.6.828)

Clark AJ, McLoughlin L \& Grossman A 1993 Familial glucocorticoid deficiency associated with point mutation in the adrenocorticotropin receptor. Lancet 341 461-462. (doi:10.1016/0140-6736(93)90208-X) 
Clark AJ, Metherell LA, Cheetham ME \& Huebner A 2005 Inherited ACTH insensitivity illuminates the mechanisms of ACTH action. Trends in Endocrinology and Metabolism 16 451-457. (doi:10.1016/j.tem.2005. 10.006)

Cone RD, Mountjoy KG, Robbins LS, Nadeau JH, Johnson KR, Roselli-Rehfuss L \& Mortrud MT 1993 Cloning and functional characterization of a family of receptors for the melanotropic peptides. Annals of the New York Academy of Sciences $680342-363$. (doi:10.1111/j. 1749-6632.1993.tb19694.x)

Cooray SN, Almiro Do Vale I, Leung KY, Webb TR, Chapple JP, Egertova M, Cheetham ME, Elphick MR \& Clark AJ 2008 The melanocortin 2 receptor accessory protein exists as a homodimer and is essential for the function of the melanocortin 2 receptor in the mouse $y 1$ cell line. Endocrinology 149 1935-1941. (doi:10.1210/en.2007-1463)

Costa JL, Forbes S, Brennan MB \& Hochgeschwender U 2011 Genetic modifications of mouse proopiomelanocortin peptide processing. Molecular and Cellular Endocrinology 336 14-22. (doi:10.1016/j.mce. 2010.12.032)

Farooqi IS, Keogh JM, Yeo GS, Lank EJ, Cheetham T \& O'Rahilly S 2003 Clinical spectrum of obesity and mutations in the melanocortin 4 receptor gene. New England Journal of Medicine 348 1085-1095. (doi:10.1056/NEJMoa022050)

Feng N, Young SF, Aguilera G, Puricelli E, Adler-Wailes DC, Sebring NG \& Yanovski JA 2005 Co-occurrence of two partially inactivating polymorphisms of MC3R is associated with pediatric-onset obesity. Diabetes 54 2663-2667. (doi:10.2337/diabetes.54.9.2663)

Gantz I, Konda Y, Tashiro T, Shimoto Y, Miwa H, Munzert G, Watson SJ, DelValle J \& Yamada T 1993 Molecular cloning of a novel melanocortin receptor. Journal of Biological Chemistry 268 8246-8250.

Getting SJ, Gibbs L, Clark AJ, Flower RJ \& Perretti M 1999 POMC genederived peptides activate melanocortin type 3 receptor on murine macrophages, suppress cytokine release, and inhibit neutrophil migration in acute experimental inflammation. Journal of Immunology 162 7446-7453.

Gorrigan RJ, Guasti L, King P, Clark AJ \& Chan LF 2011 Localisation of the melanocortin-2-receptor and its accessory proteins in the developing and adult adrenal gland. Journal of Molecular Endocrinology 46 227-232. (doi:10.1530/JME-11-0011)

Herman JP \& Cullinan WE 1997 Neurocircuitry of stress: central control of the hypothalamo-pituitary-adrenocortical axis. Trends in Neurosciences 20 78-84. (doi:10.1016/S0166-2236(96)10069-2)

Hofland J, Delhanty PJ, Steenbergen J, Hofland LJ, van Koetsveld PM, van Nederveen FH, de Herder WW, Feelders RA \& de Jong FH 2012 Melanocortin 2 receptor-associated protein (MRAP) and MRAP2 in human adrenocortical tissues: regulation of expression and association with ACTH responsiveness. Journal of Clinical Endocrinology and Metabolism 97 E747-E754. (doi:10.1210/jc.2011-2328)

Huszar D, Lynch CA, Fairchild-Huntress V, Dunmore JH, Fang Q, Berkemeier LR, Gu W, Kesterson RA, Boston BA, Cone RD et al. 1997 Targeted disruption of the melanocortin-4 receptor results in obesity in mice. Cell 88 131-141. (doi:10.1016/S0092-8674(00)81865-6)

Ito N, Ito T, Kromminga A, Bettermann A, Takigawa M, Kees F, Straub RH \& Paus R 2005 Human hair follicles display a functional equivalent of the hypothalamic-pituitary-adrenal axis and synthesize cortisol. FASEB Journal 19 1332-1334.

Izumi S, Abe K, Hayashi T, Nakane PK \& Koji T 2004 Immunohistochemical localization of the ACTH (MC-2) receptor in the rat placenta and adrenal gland. Archives of Histology and Cytology 67 443-453. (doi:10.1679/aohc.67.443)

Krieger DT 1982 Placenta as a source of 'brain' and 'pituitary' hormones. Biology of Reproduction 26 55-71. (doi:10.1095/biolreprod26.1.55)

Labbe O, Desarnaud F, Eggerickx D, Vassart G \& Parmentier M 1994 Molecular cloning of a mouse melanocortin 5 receptor gene widely expressed in peripheral tissues. Biochemistry 33 4543-4549. (doi:10.1021/bi00181a015)
Latronico AC, Reincke M, Mendonca BB, Arai K, Mora P, Allolio B, Wajchenberg BL, Chrousos GP \& Tsigos C 1995 No evidence for oncogenic mutations in the adrenocorticotropin receptor gene in human adrenocortical neoplasms. Journal of Clinical Endocrinology and Metabolism 80 875-877. (doi:10.1210/jc.80.3.875)

Lee YS, Poh LK, Kek BL \& Loke KY 2008 Novel melanocortin 4 receptor gene mutations in severely obese children. Clinical Endocrinology 68 529-535. (doi:10.1111/j.1365-2265.2007.03071.x)

Lein ES, Hawrylycz MJ, Ao N, Ayres M, Bensinger A, Bernard A, Boe AF, Boguski MS, Brockway KS, Byrnes EJ et al. 2007 Genome-wide atlas of gene expression in the adult mouse brain. Nature 445 168-176. (doi:10.1038/nature05453)

Lim BK, Huang KW, Grueter BA, Rothwell PE \& Malenka RC 2012 Anhedonia requires MC4R-mediated synaptic adaptations in nucleus accumbens. Nature 487 183-189. (doi:10.1038/nature11160)

Lindberg C, Hjorth E, Post C, Winblad B \& Schultzberg M 2005 Cytokine production by a human microglial cell line: effects of $\beta$-amyloid and $\alpha$-melanocyte-stimulating hormone. Neurotoxicity Research 8 267-276. (doi:10.1007/BF03033980)

Lowenberg M, Stahn C, Hommes DW \& Buttgereit F 2008 Novel insights into mechanisms of glucocorticoid action and the development of new glucocorticoid receptor ligands. Steroids 73 1025-1029. (doi:10.1016/ j.steroids.2007.12.002)

Lubrano-Berthelier C, Durand E, Dubern B, Shapiro A, Dazin P, Weill J, Ferron C, Froguel P \& Vaisse C 2003 Intracellular retention is a common characteristic of childhood obesity-associated MC4R mutations. Human Molecular Genetics 12 145-153. (doi:10.1093/hmg/ddg016)

Maffei M, Fei H, Lee GH, Dani C, Leroy P, Zhang Y, Proenca R, Negrel R, Ailhaud G \& Friedman JM 1995 Increased expression in adipocytes of $o b$ RNA in mice with lesions of the hypothalamus and with mutations at the $d b$ locus. PNAS 92 6957-6960. (doi:10.1073/pnas.92.15.6957)

Marsh DJ, Hollopeter G, Huszar D, Laufer R, Yagaloff KA, Fisher SL, Burn P \& Palmiter RD 1999 Response of melanocortin-4 receptor-deficient mice to anorectic and orexigenic peptides. Nature Genetics 21 119-122. (doi:10.1038/5070)

Menssen A, Haupl T, Sittinger M, Delorme B, Charbord P \& Ringe J 2011 Differential gene expression profiling of human bone marrow-derived mesenchymal stem cells during adipogenic development. BMC Genomics 12 461. (doi:10.1186/1471-2164-12-461)

Metherell LA, Chapple JP, Cooray S, David A, Becker C, Ruschendorf F, Naville D, Begeot M, Khoo B, Nurnberg P et al. 2005 Mutations in MRAP, encoding a new interacting partner of the ACTH receptor, cause familial glucocorticoid deficiency type 2. Nature Genetics 37 166-170. (doi:10.1038/ng1501)

Mitani F, Mukai K, Miyamoto H, Suematsu M \& Ishimura Y 2003 The undifferentiated cell zone is a stem cell zone in adult rat adrenal cortex. Biochimica et Biophysica Acta 1619 317-324. (doi:10.1016/S03044165(02)00490-7)

Morgan C \& Cone RD 2006 Melanocortin-5 receptor deficiency in mice blocks a novel pathway influencing pheromone-induced aggression. Behavior Genetics 36 291-300. (doi:10.1007/s10519-005-9024-9)

Mountjoy KG, Robbins LS, Mortrud MT \& Cone RD 1992 The cloning of a family of genes that encode the melanocortin receptors. Science $\mathbf{2 5 7}$ 1248-1251. (doi:10.1126/science.1325670)

Nimura M, Udagawa J, Hatta T, Hashimoto R \& Otani H 2006 Spatial and temporal patterns of expression of melanocortin type 2 and 5 receptors in the fetal mouse tissues and organs. Anatomy and Embryology 211 109-117. (doi:10.1007/s00429-005-0066-9)

Noon LA, Franklin JM, King PJ, Goulding NJ, Hunyady L \& Clark AJ 2002 Failed export of the adrenocorticotrophin receptor from the endoplasmic reticulum in non-adrenal cells: evidence in support of a requirement for a specific adrenal accessory factor. Journal of Endocrinology 174 17-25. (doi:10.1677/joe.0.1740017)

Norman D, Isidori AM, Frajese V, Caprio M, Chew SL, Grossman AB, Clark AJ, Michael Besser G \& Fabbri A 2003 ACTH and $\alpha$-MSH inhibit leptin expression and secretion in 3T3-L1 adipocytes: model for a central- 
peripheral melanocortin-leptin pathway. Molecular and Cellular Endocrinology 200 99-109. (doi:10.1016/S0303-7207(02)00410-0)

O'Shaughnessy PJ, Fleming LM, Jackson G, Hochgeschwender U, Reed P \& Baker PJ 2003 Adrenocorticotropic hormone directly stimulates testosterone production by the fetal and neonatal mouse testis. Endocrinology 144 3279-3284. (doi:10.1210/en.2003-0277)

Ogawa K, Matsui H, Ohtsuka S \& Niwa H 2004 A novel mechanism for regulating clonal propagation of mouse ES cells. Genes to Cells 9 471-477. (doi:10.1111/j.1356-9597.2004.00736.x)

Petraglia F, Sawchenko PE, Rivier J \& Vale W 1987 Evidence for local stimulation of ACTH secretion by corticotropin-releasing factor in human placenta. Nature 328 717-719. (doi:10.1038/328717a0)

Reinick CL, Liang L, Angleson JK \& Dores RM 2012 Identification of an MRAP-independent melanocortin-2 receptor: functional expression of the cartilaginous fish, Callorhinchus milii, melanocortin-2 receptor in CHO cells. Endocrinology 153 4757-4765.

Robbins LS, Nadeau JH, Johnson KR, Kelly MA, Roselli-Rehfuss L, Baack E, Mountjoy KG \& Cone RD 1993 Pigmentation phenotypes of variant extension locus alleles result from point mutations that alter MSH receptor function. Cell 72 827-834. (doi:10.1016/0092-8674 (93)90572-8)

Roselli-Rehfuss L, Mountjoy KG, Robbins LS, Mortrud MT, Low MJ, Tatro JB, Entwistle ML, Simerly RB \& Cone RD 1993 Identification of a receptor for $\gamma$ melanotropin and other proopiomelanocortin peptides in the hypothalamus and limbic system. PNAS 90 8856-8860. (doi:10.1073/ pnas.90.19.8856)

Roy S, Rached M \& Gallo-Payet N 2007 Differential regulation of the human adrenocorticotropin receptor [melanocortin-2 receptor (MC2R)] by human MC2R accessory protein isoforms $\alpha$ and $\beta$ in isogenic human embryonic kidney 293 cells. Molecular Endocrinology 21 1656-1669. (doi:10.1210/me.2007-0041)

Roy S, Roy SJ, Pinard S, Agulleiro MJ, Cerda-Reverter JM, Parent JL \& Gallo-Payet N 2012 The C-terminal domains of melanocortin-2 receptor (MC2R) accessory proteins (MRAP1) influence their localization and ACTH-induced CAMP production. General and Comparative Endocrinology 176 265-274. (doi:10.1016/j.ygcen.2012.02.003)

Rumie H, Metherell LA, Clark AJ, Beauloye V \& Maes M 2007 Clinical and biological phenotype of a patient with familial glucocorticoid deficiency type 2 caused by a mutation of melanocortin 2 receptor accessory protein. European Journal of Endocrinology 157 539-542. (doi:10.1530/EJE-07-0242)

Saito H, Kubota M, Roberts RW, Chi Q \& Matsunami H 2004 RTP family members induce functional expression of mammalian odorant receptors. Cell 119 679-691. (doi:10.1016/j.cell.2004.11.021)

Sawchenko PE \& Swanson LW 1985 Localization, colocalization, and plasticity of corticotropin-releasing factor immunoreactivity in rat brain. Federation Proceedings 44 221-227.

Schimmer BP, Kwan WK, Tsao J \& Qiu R 1995 Adrenocorticotropinresistant mutants of the $\mathrm{Y} 1$ adrenal cell line fail to express the adrenocorticotropin receptor. Journal of Cellular Physiology 163 164-171. (doi:10.1002/jcp.1041630119)

Sebag JA \& Hinkle PM 2007 Melanocortin-2 receptor accessory protein MRAP forms antiparallel homodimers. PNAS 104 20244-20249. (doi:10.1073/pnas.0708916105)

Sebag JA \& Hinkle PM 2009a Opposite effects of the melanocortin-2 (MC2) receptor accessory protein MRAP on MC2 and MC5 receptor dimerization and trafficking. Journal of Biological Chemistry $\mathbf{2 8 4}$ 22641-22648. (doi:10.1074/jbc.M109.022400)

Sebag JA \& Hinkle PM 2009b Regions of melanocortin 2 (MC2) receptor accessory protein necessary for dual topology and MC2 receptor trafficking and signaling. Journal of Biological Chemistry 284 610-618. (doi:10.1074/jbc.M804413200)

Sebag JA \& Hinkle PM 2010 Regulation of G protein-coupled receptor signaling: specific dominant-negative effects of melanocortin 2 receptor accessory protein 2. Science Signaling 3 ra28. (doi:10.1126/ scisignal.2000593)
Shenker Y, Villareal JZ, Sider RS \& Grekin RJ $1985 \alpha$-Melanocytestimulating hormone stimulation of aldosterone secretion in hypophysectomized rats. Endocrinology 116 138-141. (doi:10.1210/endo116-1-138)

Shepard TH, Landing BH \& Mason DG 1959 Familial Addison's disease; case reports of two sisters with corticoid deficiency unassociated with hypoaldosteronism. A.M.A. American Journal of Diseases of Children 97 154-162. (doi:10.1001/archpedi.1959.02070010156002)

Simamura E, Shimada H, Higashi N, Uchishiba M, Otani H \& Hatta T 2010 Maternal leukemia inhibitory factor (LIF) promotes fetal neurogenesis via a LIF-ACTH-LIF signaling relay pathway. Endocrinology 151 1853-1862. (doi:10.1210/en.2009-0985)

Simard M, Cote M, Provost PR \& Tremblay Y 2010 Expression of genes related to the hypothalamic-pituitary-adrenal axis in murine fetal lungs in late gestation. Reproductive Biology and Endocrinology 8134. (doi:10.1186/1477-7827-8-134)

Slominski A, Ermak G \& Mihm M 1996 ACTH receptor, CYP11A1, CYP17 and CYP21A2 genes are expressed in skin. Journal of Clinical Endocrinology and Metabolism 81 2746-2749. (doi:10.1210/jc.81.7.2746)

Spiga F, Waite EJ, Liu Y, Kershaw YM, Aguilera G \& Lightman SL 2011 ACTH-dependent ultradian rhythm of corticosterone secretion. Endocrinology 152 1448-1457. (doi:10.1210/en.2010-1209)

Stutzmann F, Vatin V, Cauchi S, Morandi A, Jouret B, Landt O, Tounian P, Levy-Marchal C, Buzzetti R, Pinelli L et al. 2007 Non-synonymous polymorphisms in melanocortin-4 receptor protect against obesity: the two facets of a Janus obesity gene. Human Molecular Genetics 16 1837-1844. (doi:10.1093/hmg/ddm132)

Swords FM, Baig A, Malchoff DM, Malchoff CD, Thorner MO, King PJ, Hunyady L \& Clark AJ 2002 Impaired desensitization of a mutant adrenocorticotropin receptor associated with apparent constitutive activity. Molecular Endocrinology 16 2746-2753. (doi:10.1210/me. 2002-0099)

Thornwall M, Dimitriou A, Xu X, Larsson E \& Chhajlani V 1997 Immunohistochemical detection of the melanocortin 1 receptor in human testis, ovary and placenta using specific monoclonal antibody. Hormone Research 48 215-218. (doi:10.1159/000185518)

Turan S, Hughes C, Atay Z, Guran T, Haliloglu B, Clark AJ, Bereket A \& Metherell LA 2012 An atypical case of familial glucocorticoid deficiency without pigmentation caused by coexistent homozygous mutations in MC2R (T152K) and MC1R (R160W). Journal of Clinical Endocrinology and Metabolism 97 E771-E774. (doi:10.1210/jc.2011-2414)

Vaisse C, Clement K, Guy-Grand B \& Froguel P 1998 A frameshift mutation in human MC4R is associated with a dominant form of obesity. Nature Genetics 20 113-114. (doi:10.1038/2407)

Vale W, Spiess J, Rivier C \& Rivier J 1981 Characterization of a 41-residue ovine hypothalamic peptide that stimulates secretion of corticotropin and $\beta$-endorphin. Science 213 1394-1397. (doi:10.1126/science. 6267699)

Valverde P, Healy E, Jackson I, Rees JL \& Thody AJ 1995 Variants of the melanocyte-stimulating hormone receptor gene are associated with red hair and fair skin in humans. Nature Genetics 11 328-330. (doi:10.1038/ ng1195-328)

Valverde P, Healy E, Sikkink S, Haldane F, Thody AJ, Carothers A, Jackson IJ \& Rees JL 1996 The Asp84Glu variant of the melanocortin 1 receptor (MC1R) is associated with melanoma. Human Molecular Genetics 5 1663-1666. (doi:10.1093/hmg/5.10.1663)

Vinson GP, Whitehouse BJ, Dell A, Etienne T \& Morris HR 1980 Characterisation of an adrenal zona glomerulosa-stimulating component of posterior pituitary extracts as $\alpha$-MSH. Nature $\mathbf{2 8 4}$ 464-467. (doi:10.1038/284464a0)

Webb TR \& Clark AJ 2010 Minireview: the melanocortin 2 receptor accessory proteins. Molecular Endocrinology 24 475-484. (doi:10.1210/ me.2009-0283)

Webb TR, Chan L, Cooray SN, Cheetham ME, Chapple JP \& Clark AJ 2009 Distinct melanocortin 2 receptor accessory protein domains are required 
for melanocortin 2 receptor interaction and promotion of receptor trafficking. Endocrinology 150 720-726. (doi:10.1210/en.2008-0941)

Weber A, Clark AJ, Perry LA, Honour JW \& Savage MO 1997 Diminished adrenal androgen secretion in familial glucocorticoid deficiency implicates a significant role for ACTH in the induction of adrenarche. Clinical Endocrinology 46 431-437. (doi:10.1046/j.1365-2265.1997.1580969.x)

Wikberg JE 1999 Melanocortin receptors: perspectives for novel drugs. European Journal of Pharmacology 375 295-310. (doi:10.1016/S00142999(99)00298-8)

Xing Y, Parker CR, Edwards M \& Rainey WE 2010 ACTH is a potent regulator of gene expression in human adrenal cells. Journal of Molecular Endocrinology 45 59-68. (doi:10.1677/JME-10-0006)
Xu A, Choi KL, Wang Y, Permana PA, Xu LY, Bogardus C \& Cooper GJ 2002 Identification of novel putative membrane proteins selectively expressed during adipose conversion of 3T3-L1 cells. Biochemical and Biophysical Research Communications 293 1161-1167. (doi:10.1016/ S0006-291X(02)00354-6)

Yeo GS, Farooqi IS, Aminian S, Halsall DJ, Stanhope RG \& O'Rahilly S 1998 A frameshift mutation in MC4R associated with dominantly inherited human obesity. Nature Genetics 20 111-112. (doi:10.1038/2404)

Zhang Y, Proenca R, Maffei M, Barone M, Leopold L \& Friedman JM 1994 Positional cloning of the mouse obese gene and its human homologue. Nature 372 425-432. (doi:10.1038/372425a0)

Received in final form 30 January 2013

Accepted 11 February 2013

Accepted Preprint published online 11 February 2013
C 2013 Society for Endocrinology Printed in Great Britain
Published by Bioscientifica Ltd. 